\title{
Physiological Estrogen Replacement Therapy for Puberty Induction in Girls: A Clinical Observational Study
}

\author{
Carina Ankarberg-Lindgren ${ }^{a}$ Berit Kriström ${ }^{b}$ Ensio Norjavaara ${ }^{a}$ \\ ${ }^{a}$ Göteborg Pediatric Growth Research Center, Department of Pediatrics, Institute of Clinical Sciences,

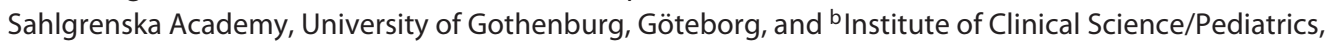 \\ Umeå University, Umeå, Sweden
}

\section{Key Words}

Estrogen deficiency $\cdot$ Hormone replacement therapy, transdermal · Ovarian failure · Turner syndrome · Growth

\begin{abstract}
Background/Aim: The goal of estrogen replacement therapy (ERT) in girls with hypogonadism is to achieve the endocrine milieu similar to natural puberty, where transdermal administration is the most physiological route. The aim of the study was to evaluate guidelines for the induction of puberty with transdermal estradiol $\left(E_{2}\right)$ patches in a large outpatient setting. Methods: In a retrospective study, serum $E_{2}$ levels from 18 clinics were analyzed at the Göteborg Pediatric Growth Research Center laboratory, as part of the initiation of ERT in girls with hypogonadism. Exclusion criteria were pubertas tarda and pubertal arrest. Eighty-eight observations (50 with Turner syndrome, TS) were included. Serum $E_{2}$ levels were determined by extraction + radioimmunoassay (detection limit $4 \mathrm{pmol} / \mathrm{l})$ and analyzed in relation to the dose of Evorel ${ }^{\circledR}$ ( $25 \mu \mathrm{g} / 24 \mathrm{~h}$, containing $1.60 \mathrm{mg}$ estradiol hemihydrate; Janssen-Cilag Pharmaceutica N.V., Beerse, Belgium). Results: There was a linear relationship between serum $E_{2}$ and the weight-based dose, with $r=0.56, p<0.0001$ for all observations and $r=0.59, p<0.0001$ for the TS study group. Linear
\end{abstract}

regression analysis for doses of $0.05-0.07 \mu \mathrm{g} / \mathrm{kg}$ resulted in serum levels of 17-23 pmol/l (TS 17-24 pmol/l) and doses of $0.08-0.12 \mu \mathrm{g} / \mathrm{kg}$ in $26-39 \mathrm{pmol} / \mathrm{l}$ (TS $27-39 \mathrm{pmol} / \mathrm{l})$. Conclusions: For the initiation of ERT with nocturnally administered $E_{2}$ patches, we recommend reduced starting doses of 0.05$0.07 \mu \mathrm{g} / \mathrm{kg}$, with the goal of mimicking $E_{2}$ levels during gonadarche. In older girls, when breast development is of high priority, the starting dose can still be $0.08-0.12 \mu \mathrm{g} / \mathrm{kg}$.

(c) 2014 S. Karger AG, Basel

\section{Introduction}

The overall goal of estrogen replacement therapy (ERT) in girls with hypogonadism is to establish an ageappropriate endocrine milieu resulting in normal growth, bone mass accrual, uterine growth and maturation, development of secondary sexual characteristics and cognitive functions, at a tempo consistent with the peer group [1, $2]$. The very early part of the pubertal growth spurt and the development of secondary sexual characteristics are regulated by increasing serum levels of nocturnal estrogens, where low serum estrogen levels are growth promoting and higher levels are needed for complete breast and body development $[3,4]$.

\section{KARGER}

E-Mail karger@karger.com

www.karger.com/hrp (c) 2014 S. Karger AG, Basel

$1663-2818 / 14 / 0814-0239 \$ 39.50 / 0$
Ensio Norjavaara, MD, $\mathrm{PhD}$

Göteborg Pediatric Growth Research Center, Department of Pediatrics Institute of Clinical Sciences, Sahlgrenska Academy, University of Gothenburg SE-416 85 Göteborg (Sweden)

E-Mail ensio.norjavaara@vgregion.se 
How to cut Evorel patch $25 \mu \mathrm{g}$
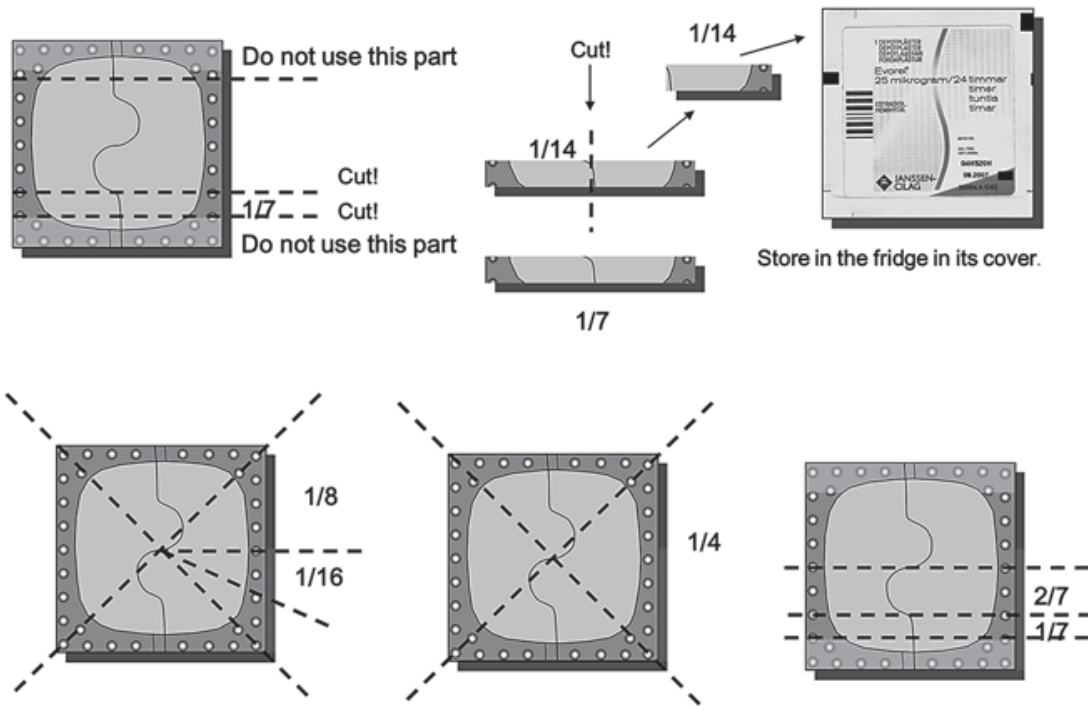

Fig. 1. Cutting instructions for $1 / 14$ to 2/7 Evorel patches (Systen; Janssen-Cilag Pharmaceutica; $25 \mu \mathrm{g} / 24 \mathrm{~h}$ ).

Thereby, pubertal ERT consists of two major parts: first, low estrogen doses to promote onset of pubertal growth; second, increased estrogen doses to finalize the pubertal development. In a girl with hypogonadism, the optimal estrogen treatment route, drug, dose and dosing tempo have to be determined for the individual patient. Many of these decisions are based on tradition, rather than on evidence.

Current dosing guidelines are based on the investigation of nocturnal application of transdermal patches in a limited number of hospitalized patients [5]. The aim of the present retrospective study was to use a large set of empirical data to evaluate the current dosing guidelines for initiation of ERT to achieve morning estradiol $\left(\mathrm{E}_{2}\right)$ levels similar to those seen during the very first signs of spontaneous puberty.

\section{Subjects and Methods}

\section{Study Group}

The study group consisted of girls with hypogonadism. Girls treated with nocturnal application of Evorel ${ }^{\circledR}$ patches $(25 \mu \mathrm{g} / 24 \mathrm{~h}$, containing 1.60 mg estradiol hemihydrate) during the years 20012011 were included in the potential study group. Inclusion criteria were those treated with doses of $0.05-0.15 \mu \mathrm{g} / \mathrm{kg}$ body weight. Exclusion criteria were girls with pubertas tarda or pubertal arrest. Lack of information on $\mathrm{E}_{2}$ patch dose, body weight or time of blood sampling also resulted in exclusion. We did not have sufficiently reliable data on breast development in relation to dose in the study group, and pretreatment $\mathrm{E}_{2}$ samples were not always available; for some girls, we were obliged to rely on the referral information on hypogonadism and the absence of pubertal development.

In total, 142 fulfilled the inclusion criteria derived from 54 girls. Repeated $\mathrm{E}_{2}$ determinations on subjects during treatment with the same $\mathrm{E}_{2}$ dose per kilogram body weight (rounded to two decimals) were identified in 28 subjects with 2-5 samplings per girl and dose. For these observations, the median values were calculated and used in the study, which reduced the observations to 88 .

In all, 88 observations from 54 individuals were included. The diagnoses given on the referrals were Turner syndrome (TS) in 31, other reasons for primary ovarian failure in 7 , hypopituitarism in 7 , androgen resistance (gonadectomized) in 3 and ovarian failure due to chemotherapy in 6 . The age range was $10.5-16.9$ years $(\mathrm{n}=$ 29 , median 14.1 years) for doses of $0.05-0.07 \mu \mathrm{g} / \mathrm{kg}, 9.9-18.0$ years ( $\mathrm{n}=42$, median 14.0 years) for doses of $0.08-0.12 \mu \mathrm{g} / \mathrm{kg}$ and $11.7-$ 17.0 years $(\mathrm{n}=17$, median 14.7 years) for doses of $0.13-0.15 \mu \mathrm{g} / \mathrm{kg}$.

Design

We recommended cutting the matrix patches (Evorel $=$ Systen ${ }^{\circledR} ; 25 \mu \mathrm{g} / 24 \mathrm{~h}$, containing $1.55 \mathrm{mg} \mathrm{E} \mathrm{E}_{2}$ as 1.60 estradiol hemihydrate; Janssen-Cilag Pharmaceutica N.V., Beerse, Belgium) to obtain a dose of $0.08-0.12 \mu \mathrm{g} / \mathrm{kg}$ as the puberty induction starting dose [5]; see figure 1 for cutting instructions. However, during the 10 -year period of this study, pediatricians have started to use lower doses than the recommended guideline. It is recommended to place the patch on the superior lateral glutea in the evening at bedtime and remove it the following morning [5], resulting in approximately $10 \mathrm{~h}$ of treatment. Within 1-2 weeks of the start of treatment, physicians were recommended to monitor the morning serum $E_{2}$ with the patch still in situ, in order to adjust the dose if the target $\mathrm{E}_{2}$ range was not reached. 
Study Material

The retrospective study consisted of registered serum $\mathrm{E}_{2}$ levels from samples sent for analysis to the Göteborg Pediatric Growth Research Center laboratory, at the Queen Silvia Children's Hospital, Göteborg, Sweden. All clinical information on the referrals was recorded, together with the assay result. The samples were submitted from 18 clinics in Sweden. Included were those girls who broadly followed the guidelines by Ankarberg-Lindgren et al. [5] for puberty induction with ERT. With this retrospective design, the study lacks confirmatory clinical and laboratory data on the diagnosis. The analysis has to rely on the diagnosis recorded. Furthermore, no information of compliance was found.

\section{$E_{2}$ Determination}

Serum $\mathrm{E}_{2}$ concentrations were determined in duplicate by an assay which involves a diethyl ether extraction step prior to radioimmunoassay (Spectria ${ }^{\circledR}$ Estradiol RIA; Orion Diagnostica, Espoo, Finland) $[1,6]$. The extraction $\mathrm{E}_{2}$ radioimmunoassay has been validated especially for pediatric use [6] and is accredited by the SWEDAC quality control agency in Sweden, SS-EN ISO 15189 (No. 1899). The lower limit of detection was $4 \mathrm{pmol} / \mathrm{l}$. The crossreactivity of the $\mathrm{E}_{2}$ antiserum was below $1 \%$ for $30 \mathrm{E}_{2}$-related steroids. The intra-assay coefficient of variation was $8-17 \%$ for concentrations in the $4-100 \mathrm{pmol} / \mathrm{l}$ range, while the interassay coefficient of variation was $19 \%$ at $6 \mathrm{pmol} / \mathrm{l}$, below $12 \%$ for $10-40$ $\mathrm{pmol} / \mathrm{l}$, and below $10 \%$ for $70 \mathrm{pmol} / \mathrm{l}$ and above.

\section{Statistical Analyses}

Relationships between $\mathrm{E}_{2}$ dose and obtained serum $\mathrm{E}_{2}$ were estimated with Pearson's correlation analyses. Linear regression analysis and correlation analysis were performed with Origin 9.0, OriginLab Corp., Northampton, Mass., USA. For girls in whom more than one observation was made for a given dose, the median was used in the statistical analyses.

\section{Ethics Statement}

Informed consent was obtained, in accordance with the Swedish Biobank Act (Biobankslagen SFS 2002:297), in the form of parental agreement to the inclusion of their child's samples and referrals in a biobank.

\section{Results}

\section{All Kinds of Hypogonadism}

For the 29 girls who started ERT at $0.05-0.07 \mu \mathrm{g} / \mathrm{kg}$, all had serum $\mathrm{E}_{2}$ levels above the reference interval for prepuberty (B1) [7]. Sixteen of them had levels in the peripubertal range (7-24 pmol/l), Tanner breast stage 1-2 (B12 ), while 12 were within the reference interval for Tanner breast stage $2(\mathrm{~B} 2 ; 24-47 \mathrm{pmol} / \mathrm{l})$, and 1 was just above the $\mathrm{B} 2$ range (fig. $2 \mathrm{a}$ ).

Of the 42 girls receiving the dose $0.08-0.12 \mu \mathrm{g} / \mathrm{kg}, 20$ still had low levels corresponding to B1-2; 18 had serum $\mathrm{E}_{2}$ within the reference interval for B2, while 4 had levels above the B2 interval (fig. 2a).

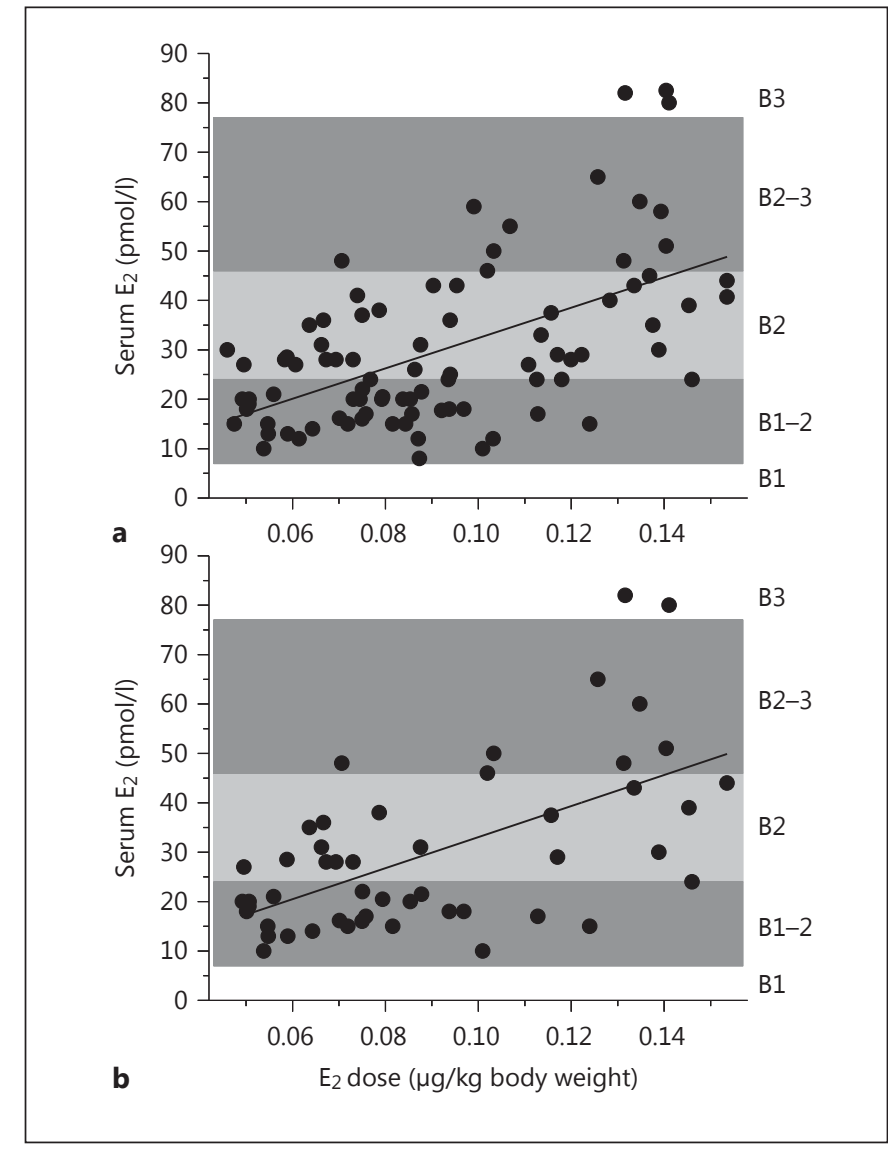

Fig. 2. Serum $E_{2}$ concentrations in relation to $E_{2}$ dose per kilogram body weight from a matrix patch (Evorel; $25 \mu \mathrm{g} / 24 \mathrm{~h}$, containing $1.60 \mathrm{mg} \mathrm{E}_{2}$ hemihydrate; Janssen-Cilag Pharmaceutica) in girls with hypogonadism. The morning serum samples were drawn with the patch still in situ. The gray area depicts the reference interval for girls in early puberty divided into three areas: peripubertal levels, i.e. levels seen during assumed gonadarche in girls with Tanner breast stage 1-2 (B1-2), breast stage 2 (B2) and the transition stage between breast stages 2 and 3 (B2-3), respectively. a Eighty-eight samples from 54 girls with any kind of hypogonadism. Linear regression analysis showed that serum $\mathrm{E}_{2}(\mathrm{pmol} / \mathrm{l})=307.2 \times \mathrm{E}_{2}$ dose $(\mu \mathrm{g} / \mathrm{kg})+$ $1.7(\mathrm{r}=0.56, \mathrm{p}<0.0001)$. $\mathbf{b}$ Fifty $\mathrm{E}_{2}$ samples from a subgroup of 31 girls with TS. Linear regression analysis showed that serum $\mathrm{E}_{2}$ $(\mathrm{pmol} / \mathrm{l})=314.3 \times \mathrm{E}_{2}$ dose $(\mu \mathrm{g} / \mathrm{kg})+1.6(\mathrm{r}=0.59, \mathrm{p}<0.0001)$.

Among the 17 girls who were treated with $0.13-0.15$ $\mu \mathrm{g} / \mathrm{kg}$, only 9 had $\mathrm{E}_{2}$ levels within the B2 interval, while 5 had $\mathrm{E}_{2}$ levels in the B2-3 interval (46-77 pmol/l) and 3 in the Tanner breast stage 3 (B3) interval. The relationship between $\mathrm{E}_{2}$ dose per kilogram body weight and the $\mathrm{E}_{2}$ serum concentration for the total group is shown in figure $2 \mathrm{a}$. Linear regression analysis for doses of $0.05-0.07 \mu \mathrm{g} /$ $\mathrm{kg}$ resulted in serum levels of $17-23 \mathrm{pmol} / \mathrm{l}$ and doses of $0.08-0.12 \mu \mathrm{g} / \mathrm{kg}$ resulted in $26-39 \mathrm{pmol} / \mathrm{l}$. 
Table 1. Doses of pubertal ERT converted to the corresponding individual patch doses

\begin{tabular}{|c|c|c|c|c|c|}
\hline $0.05-0.07$ & $\begin{aligned} \leq & 40 \\
& 41-60 \\
& 60-85 \\
> & 85\end{aligned}$ & $\begin{array}{l}1 / 14-1 / 12 \\
1 / 8 \\
1 / 7-1 / 6 \\
1 / 4\end{array}$ & $\begin{array}{l}1 / 24 \\
1 / 16 \\
1 / 14-1 / 12 \\
1 / 8\end{array}$ & $\begin{array}{l}2 \\
3 \\
4 \\
6\end{array}$ & $\begin{array}{l}\text { Mimicking peripubertal } \mathrm{E}_{2} \text { levels } \\
(7-24 \mathrm{pmol} / \mathrm{l}) \text {, which is seen in girls } \\
\text { at gonadarche, with or without } \\
\text { breast development }\end{array}$ \\
\hline
\end{tabular}

\section{Turner Syndrome}

A subgroup analysis was performed on 50 blood samples from the 31 girls with TS. A linear relationship was found between $E_{2}$ dose and obtained serum levels (fig. $2 b)$. Linear regression analysis for doses of $0.05-0.07 \mu \mathrm{g} /$ $\mathrm{kg}$ resulted in serum levels of 17-24 pmol/l and doses of $0.08-0.12 \mu \mathrm{g} / \mathrm{kg}$ resulted in $27-39 \mathrm{pmol} / \mathrm{l}$. When the two functions (TS vs. all kinds of hypogonadism) were compared, there was no significant difference.

For the 21 TS girls who started $\mathrm{E}_{2}$ treatment on 0.05 $0.07 \mu \mathrm{g} / \mathrm{kg}, 12$ had serum $\mathrm{E}_{2}$ levels within the B1-2 interval, while 8 observations were within the $\mathrm{B} 2$ interval and 1 was just above the B2 range. Furthermore, in 18 girls receiving the dose $0.08-0.12 \mu \mathrm{g} / \mathrm{kg}, 12 \mathrm{had} \mathrm{E}_{2}$ levels in the B1-2 interval, 4 were within the B2 interval, and 2 were in the interval seen both in breast stages 2 and 3 (B2-3). However, in the 11 girls who were treated with a higher dose $(0.13-0.15 \mu \mathrm{g} / \mathrm{kg}), 5$ had $\mathrm{E}_{2}$ levels within the $\mathrm{B} 2$ interval while 4 had $\mathrm{E}_{2}$ levels in the B2-3 interval and 2 in the $\mathrm{B} 3$ interval (fig. 2).

In table 1 , the obtained doses of $\mathrm{E}_{2}(\mu \mathrm{g} / \mathrm{kg})$ are converted to the corresponding individual patch doses. This study was made with $25-\mu \mathrm{g}$ patches; however, if the $25-\mu \mathrm{g}$ patches are not available, the surface of a $50-\mu \mathrm{g}$ patch is double the size of a $25-\mu$ g patch, and our results may be converted accordingly.

\section{Discussion}

We have previously published a recommendation that transdermal $\mathrm{E}_{2}$ matrix patches should be cut to administer low doses; with nocturnal application, the serum $\mathrm{E}_{2}$ levels and diurnal rhythm in normal girls undergoing puberty can be closely mimicked [5]. Our regimen has become a worldwide guideline [8-10]. However, the pub- lished guidelines were based on a limited group of hospitalized patients [5]; in the present study, we evaluated how this regimen works in an outpatient setting, using an even lower starting dose, testing a larger group of hypogonadal girls and assessing the reported dose in relation to the achieved morning level of serum $\mathrm{E}_{2}$.

The results from this study suggest that the ERT starting dose should be $0.05-0.07 \mu \mathrm{g} / \mathrm{kg}$, which is lower than in our previous study [5]. With this reduced regimen, the risk of too high a serum $\mathrm{E}_{2}$ concentration, compared to the reference interval for Tanner stage B2, will be reduced. This is also supported by recent results from girls in spontaneous puberty, demonstrating an association of serum $\mathrm{E}_{2}$ levels of 13-31 pmol/l with increased height velocity or onset of the pubertal growth spurt [3].

For clinics with access to ultrasensitive methods for determination of childhood $\mathrm{E}_{2}$, we recommend starting with a dose of $0.05-0.07 \mu \mathrm{g} / \mathrm{kg}$ and following the morning serum $\mathrm{E}_{2}$ level within 1-2 weeks, when the patient is comfortable with the regime. This makes it possible to rapidly adjust the dose if the individual target serum level is not reached.

For clinics without access to an ultrasensitive $\mathrm{E}_{2}$ assay, we recommend starting with the same dose of 0.05-0.07 $\mu \mathrm{g} / \mathrm{kg}$ and following the clinical signs of breast development or increment in uterine size by ultrasound. If no effect is found on breast development after 9-15 months, the dose can be increased. If breast development starts within 3 months, consider reducing the dose if the aim is low $\mathrm{E}_{2}$ levels in the beginning of puberty, or refraining from dose increment for at least 12 months. This consideration could be applied to other effects of $\mathrm{E}_{2}$, such as development of the uterus and advancement of bone age, but we have limited data on how $\mathrm{E}_{2}$ levels relate to uterine development, and we cannot give any recommendations on these measures. 
For those clinical situations in which breast development is a higher priority than a continued favorable growth - for example in older girls or in girls with TS and pubertal arrest - we would recommend starting with higher doses, such as $0.08-0.12 \mu \mathrm{g} / \mathrm{kg}$; these girls may already have been exposed to pubertal levels of $E_{2}$.

Our recommendation to give $4 \mu \mathrm{g}$ (1/7 to $1 / 6$ of a 25 $\mu \mathrm{g}$ patch, or $1 / 14$ to $1 / 12$ of a $50-\mu \mathrm{g}$ patch) for puberty induction in girls weighing approximately $63 \mathrm{~kg}$ is in line with obtained serum $\mathrm{E}_{2}$ concentrations in postmenopausal women using the 50- $\mu$ g Evorel patch. The average serum $\mathrm{E}_{2}$ concentration of $184 \mathrm{pmol} / \mathrm{l}$ in an average $63-\mathrm{kg}$ woman using the $50-\mu \mathrm{g}$ patch [11] is about 12 times higher than our target level for serum $\mathrm{E}_{2}$ for puberty induction; thus, our recommended dose of $4 \mu \mathrm{g}$ is $1 / 12$ of the adult dose.

Physiological age is preferable as a guide to deciding when to start the treatment, as it supports normal bone mineral accrual [12], and there is also the psychological advantage for the girl to reach puberty at the same age as her peers [13]. Earlier ERT may also improve cognitive function, as demonstrated in girls with TS [14]. For these reasons, there is international consensus to induce puberty in girls with TS around the age of 12 years [8], which is approximately 1 year later than the average pubertal onset in normal girls.

In the present study, some of the girls started ERT earlier (girls aged 9-11 years) than the recommendation from guidelines [8]. The reason for an earlier start of pubertal ERT was to mimic the peripubertal levels (gonadarche) of $E_{2}$ seen 1-2 years before the start of breast development [15]. And indeed, the present study shows that it is possible. Whether it is possible to mimic the prepubertal levels by cutting the patch to even smaller pieces needs to be studied in the future.

In our previous study, we found that low doses of $\leq 0.08 \mu \mathrm{g} / \mathrm{kg}$ may not necessarily induce breast development [5]. However, after the first administration of patches in doses of $0.08-0.12 \mu \mathrm{g} / \mathrm{kg}$, breast development occurred within 3-6 months for the majority. It was also found that girls with $E_{2}$ levels above the B2 reference interval on the initial dose developed to stage B3 within 10 months of the start of ERT [5]. Nevertheless, some girls need higher doses, possibly due to individual breast sensitivity to $E_{2}$, all drawing attention to the need for close monitoring of serum $\mathrm{E}_{2}$ levels in relation to clinical development.

There are both benefits and risks associated with pubertal ERT. The most serious risk is that no product is authorized for this indication; thus, treatment is per- formed off label with formulas intended for adults, which may result in adult $\mathrm{E}_{2}$ levels and too fast a pubertal development [16-18], or in attempts to manipulate adult doses to mimic $\mathrm{E}_{2}$ levels seen during spontaneous puberty [5, 19].

Nonetheless, transdermally administered ERT can achieve serum $E_{2}$ levels, as well as a diurnal rhythm, similar to spontaneous puberty and the associated risks are low. Transdermal ERT has minimal, if any, effect on hepatic clotting factor production and other protein changes associated with the liver first-pass effect. Whereas oral ERT in postmenopausal women is associated with an increased risk of deep vein thrombosis and pulmonary thromboembolism [20-22], breast cancer [23], reduced insulin-like growth factor-I levels, increased fat mass and reduced lean body mass [24], none of these effects are evident with transdermal ERT. Furthermore, studies on physiological sex steroid replacement therapy (transdermal $\mathrm{E}_{2}$ and progesterone) in postmenopausal women and women with premature ovarian failure resulted in lower blood pressure and improved renal function compared to oral regimens $[22,25]$. Transdermal ERT in girls with TS has shown a faster bone accrual in the spine, increased uterine growth, improved overall body composition and lower luteinizing hormone/follicle-stimulating hormone concentrations compared to oral ERT $[17,26,27]$. Moreover, ethinyl $\mathrm{E}_{2}$ - a potent synthetic estrogen used in oral contraception - has different binding properties compared to natural estrogen ( $17 \beta-E_{2}$ in transdermal preparations), in that ethinyl $E_{2}$ has a fourfold selectivity for estrogen receptor $\alpha$ compared to $17 \beta-\mathrm{E}_{2}$, which has similar selectivity for both $\alpha$ - and $\beta$-forms [28].

This is not a randomized, placebo-controlled clinical trial and has all the weaknesses that an observational study has. In addition, hospitalized patients are more closely controlled regarding the dose, compared to patients in outpatient settings. Nevertheless, even if there was a relatively high interindividual variance in the present study, we found a linear relationship between ERT dose and serum $\mathrm{E}_{2}$ levels, in the TS group as well as in the group with hypogonadism of various etiologies. Although $\mathrm{E}_{2}$ levels of $24-30 \mathrm{pmol} / \mathrm{l}$ were seen over the dose range from 0.05 to $0.15 \mu \mathrm{g} / \mathrm{kg}$, a doubling of the dose resulted in an approximate doubling of the serum $\mathrm{E}_{2}$ level. This indicates that the results may be applied to any kind of hypogonadism.

We conclude that for the initiation of ERT in order to induce pubertal development with the nocturnally administered patch, the recommended starting dose is 
$0.05-0.07 \mu \mathrm{g} / \mathrm{kg}$, equivalent to $2-6 \mu \mathrm{g}$ from an $\mathrm{E}_{2}$ patch. In older girls, when breast development is a high priority, the starting dose can be $0.08-0.12 \mu \mathrm{g} / \mathrm{kg}$, corresponding to 3-7 $\mu \mathrm{g}$ from an $E_{2}$ patch.

\section{Acknowledgments}

This work was supported by grants from the Sahlgrenska Academy at the University of Gothenburg, the Swedish Medical Research Council, the Petter Silfverskiöld Foundation and the
Northern County Councils Cooperation Committee (Visare Norr). We wish to thank the staff at the Göteborg Pediatric Growth Research Center laboratory at the Queen Silvia Children's Hospital in Göteborg, especially Ann-Marie Månqvist and Irène Leonardsson. We are also grateful to all the pediatricians who submitted samples to the laboratory, enabling us to establish the ERT target dose.

\section{Disclosure Statement}

C.A.-L., B.K. and E.N. declare no conflicts of interest.

\section{References}

1 Norjavaara E, Ankarberg C, Albertsson-Wikland K: Diurnal rhythm of 17 beta-estradiol secretion throughout pubertal development in healthy girls: evaluation by a sensitive radioimmunoassay. J Clin Endocrinol Metab 1996;81:4095-4102.

-2 Ankarberg-Lindgren C, Norjavaara E: Estradiol in pediatric endocrinology. Am J Clin Pathol 2009;132:978-980.

- 3 Albin AK, Niklasson A, Westgren U, Norjavaara $\mathrm{E}$ : Estradiol and pubertal growth in girls. Horm Res Paediatr 2012;78:218-225.

4 Janner M, Fluck CE, Mullis PE: Impact of estrogen replacement throughout childhood on growth, pituitary-gonadal axis and bone in a 46,XX patient with CYP19A1 deficiency. Horm Res Paediatr 2012;78:261-268.

-5 Ankarberg-Lindgren C, Elfving M, Wikland KA, Norjavaara E: Nocturnal application of transdermal estradiol patches produces levels of estradiol that mimic those seen at the onset of spontaneous puberty in girls. J Clin Endocrinol Metab 2001;86:3039-3044.

6 Ankarberg-Lindgren C, Norjavaara E: A purification step prior to commercial sensitive immunoassay is necessary to achieve clinical usefulness when quantifying serum 17betaestradiol in prepubertal children. Eur J Endocrinol 2008;158:117-124.

7 Ankarberg-Lindgren C, Mahler TB, Norjavaara $\mathrm{E}$ : Biological reference intervals for serum estradiol and testosterone in children. Horm Res Paediatr 2013;80(suppl 1):179.

8 Bondy CA, Turner Syndrome Study G: care of girls and women with Turner syndrome: a guideline of the Turner Syndrome Study Group. J Clin Endocrinol Metab 2007;92:1025.

9 Davenport ML: Approach to the patient with Turner syndrome. J Clin Endocrinol Metab 2010;95:1487-1495.

10 Palmert MR, Dunkel L: Clinical practice. Delayed puberty. N Engl J Med 2012;366:443453.

11 Reginster JY, Albert A, Deroisy R, Colette J, Vrijens B, Blacker C, Brion N, Caulin F, Mayolle C, Regnard A, Scholler R, Franchimont P: Plasma estradiol concentrations and pharma- cokinetics following transdermal application of Menorest 50 or Systen (Evorel) 50. Maturitas 1997;27:179-186, erratum in Maturitas 1997;28:193-195.

12 Mora S, Weber G, Guarneri MP, Nizzoli G, Pasolini D, Chiumello G: Effect of estrogen replacement therapy on bone mineral content in girls with Turner syndrome. Obstet Gynecol 1992;79:747-751.

13 Carel JC, Elie C, Ecosse E, Tauber M, Leger J, Cabrol S, Nicolino M, Brauner R, Chaussain JL, Coste J: Self-esteem and social adjustment in young women with Turner syndrome - influence of pubertal management and sexuality: population-based cohort study. J Clin Endocrinol Metab 2006;91:2972-2979.

14 Ross JL, Roeltgen D, Feuillan P, Kushner H, Cutler GB Jr: Effects of estrogen on nonverbal processing speed and motor function in girls with Turner's syndrome. J Clin Endocrinol Metab 1998;83:3198-3204

15 Norjavaara E, Albertsson Wikland K, Ankarberg-Lindgren C: A sensitive estradiol assay can predict the onset of puberty before thelarche. Horm Res 2005;64(suppl 1):23.

16 Mauras N, Shulman D, Hsiang HY, Balagopal P, Welch S: Metabolic effects of oral versus transdermal estrogen in growth hormonetreated girls with Turner syndrome. J Clin Endocrinol Metab 2007;92:4154-4160.

17 Nabhan ZM, Dimeglio LA, Qi R, Perkins SM, Eugster EA: Conjugated oral versus transdermal estrogen replacement in girls with Turner syndrome: a pilot comparative study. J Clin Endocrinol Metab 2009;94:2009-2014.

18 Bannink EM, van Sassen C, van Buuren S, de Jong FH, Lequin M, Mulder PG, de Muinck Keizer-Schrama SM: Puberty induction in Turner syndrome: results of oestrogen treatment on development of secondary sexual characteristics, uterine dimensions and serum hormone levels. Clin Endocrinol (Oxf) 2009;70:265-273.

19 Piippo S, Lenko H, Kainulainen P, Sipila I: Use of percutaneous estrogen gel for induction of puberty in girls with Turner syndrome. J Clin Endocrinol Metab 2004;89: 3241-3247.
20 Scarabin PY, Oger E, Plu-Bureau G: Differential association of oral and transdermal oestrogen-replacement therapy with venous thromboembolism risk. Lancet 2003;362: 428-432.

21 Canonico M, Oger E, Plu-Bureau G, Conard J, Meyer G, Levesque H, Trillot N, Barrellier MT, Wahl D, Emmerich J, Scarabin PY, Estrogen Thromboembolism Risk Study G: Hormone therapy and venous thromboembolism among postmenopausal women: impact of the route of estrogen administration and progestogens: the Esther Study. Circulation 2007;115:840-845.

22 L'Hermite M, Simoncini T, Fuller S, Genazzani AR: Could transdermal estradiol + progesterone be a safer postmenopausal HRT? A review. Maturitas 2008;60:185-201.

23 Opatrny L, Dell'Aniello S, Assouline S, Suissa S: Hormone replacement therapy use and variations in the risk of breast cancer. $\mathrm{Br} \mathrm{J} \mathrm{Ob-}$ stet Gynaecol 2008;115:169-175; discussion 175.

24 O'Sullivan AJ, Ho KK: Route-dependent endocrine and metabolic effects of estrogen replacement therapy. J Pediatr Endocrinol Metab 2000;13(suppl 6):1457-1466.

25 Langrish JP, Mills NL, Bath LE, Warner P, Webb DJ, Kelnar CJ, Critchley HO, Newby DE, Wallace WH: Cardiovascular effects of physiological and standard sex steroid replacement regimens in premature ovarian failure. Hypertension 2009;53:805-811.

-26 Alves ST, Gallichio CT, Guimaraes MM: Insulin resistance and body composition in Turner syndrome: effect of sequential change in the route of estrogen administration. Gynecol Endocrinol 2006;22:590-594.

27 Taboada M, Santen R, Lima J, Hossain J, Singh R, Klein KO, Mauras N: Pharmacokinetics and pharmacodynamics of oral and transdermal 17beta estradiol in girls with Turner syndrome. J Clin Endocrinol Metab 2011;96:3502-3510.

28 Harris HA, Bapat AR, Gonder DS, Frail DE: The ligand binding profiles of estrogen receptors alpha and beta are species dependent. Steroids 2002;67:379-384. 